UNIVERSUM • Vol. $30 \bullet$ No $2 \cdot 2015 \bullet$ Universidad de Talca

The topic of education in Chilean political discourse during 2006-2013

Anna Ivanova

Pp. 91 a 104

\title{
THE TOPIC OF EDUCATION IN CHILEAN POLITICAL DISCOURSE DURING 2006-2013
}

\author{
El tema de la educación en los discursos políticos chilenos \\ durante el periodo 2006-2013
}

Anna Ivanova*

\begin{abstract}
This paper focuses on the analysis of the topic of education in the Chilean political discourse during 2006-2013. For this purpose the study employed corpus linguistics method for political discourse analysis. Mainly, the paper focused on eight official presidential discourses pronounced annually on the 21st of May, thus, dating from the M. Bachelet's government of 2006 to that of S. Piñera's in 2013. The results both of quantitative and qualitative analysis demonstrate: 1) A steady growth in the presence of education topic in the presidential discourses starting with its low coverage in 2006 and finishing with its maximum in 2013; 2) A close association of education with the words quality and higher; 3) Positive semantic prosody of the collocations around the node "education."

Keywords: Education in Chile, political discourse, corpus linguistics, discourse analysis, collocates, semantic prosody.
\end{abstract}

\section{RESUMEN}

Este artículo se centra en el análisis del tema de la educación en el discurso político chileno durante el periodo 2006-2013. Para lograr esto, el estudio se basa en los métodos de la lingüística de corpus para el análisis del discurso político. Principalmente, el artículo se

\footnotetext{
* Instituto de Estudios Sociales y Humanísticos, Universidad Autónoma de Chile. Santiago, Chile. Correo electrónico: anna.ivanova@uautonoma.cl

Received December, 17, 2014. Accepted January, 8, 2015.
} 
centra en ocho discursos presidenciales oficiales pronunciados anualmente cada 21 de mayo, desde el gobierno de Michelle Bachelet hasta el de Sebastián Piñera. Los resultados de los análisis cuantitativo y cualitativo demuestran: 1) Constante crecimiento del tema de educación en los discursos presidenciales empezando por su baja cobertura en 2006 y terminando con su máximo en 2013; 2) Fuerte asociación de la educación con las palabras calidad y superior; 3) Positiva prosodia semántica de las colocaciones del nodo "educación".

Palabras clave: Educación en Chile, discurso político, lingüística de corpus, análisis del discurso, colocaciones, prosodia semántica.

\section{INTRODUCTION}

The analysis of education policy and its development in Chile during the last decade agrees on the fact that the emergence of the student movement in 2006 (Penguin Revolution) has opened up a new scenario for debates about the institutionality of education system. In this new scenario the main focus of attention goes beyond simple discussion of the improvement techniques promoted by the regulatory state in the early 1990s. Rather, it sets up a new challenge aimed at redefining the existing institutionality, which in its turn, is seen as the main reason to fail in achieving quality and equity both in school and higher education systems (Cox, 2007; Bellei, Contreras \& Valenzuela, 2010).

In its turn, the abolishing the Constitutional Organic Law of Education and passing the General Law of Education has brought up important modifications of the market institutionality. This new law included two main principles: one of quality in education, and one of free education. Along with that, the law suggested significant changes in the Ministry of Education such as clear distribution of roles assigned for monitoring and evaluating the education system through the Quality Agency and the Superintendent of Education.

However, these actions have not reduced academic and public debates on the need to redefine or to restructure the market institutionality aimed at opening up a new vision on education as a social right. In so doing, it will provide high standards of equity and quality leaving behind the model of educational reforms of the 1990s as a collection of intervention programs (Iaies \& Delich, 2009). Moreover, the new changes have established a strong education - institutionality association in the society, and its results not just allowed but rather promoted the commercialization of education in Chile.

All things considered, this paper proposes to lift a curtain and see the kind of role assigned by the government to the concept of education in the country. What is more, it intends to determine essential relationships between the state and education, provided there is always an ideology behind, and "control of the 
school curriculum has long been perceived as a primary tool for maintaining and legitimating political power and ideology of those in power" (Morris \& Sweeting, 1991: 249). Besides, "the school curriculum should perform a major role in explicitly promoting a national character and identity" (Morris \& Sweeting, 1991: 249), as, e.g., in their study on education in Hong Kong, Morris \& Sweeting (1991: 249) state that "words such as hard-working, disciplined, confident and self-reliant, collective will and character, self-sacrifice, perseverance and resilience have collectively come to represent a set of values, peculiarly Asian, which need to be reinforced through education.” This involves treating education not just as a process to provide knowledge, but also as an instrument to introduce national values to the people, like in the case of Hong Kong (Morris \& Sweeting, 1991).

In this belief, one of the possible facets to approach this problem could be based on a multi-layered interpretative framework, drawing on discourse analysis, cognitive linguistics, and a corpus-based approach (McCarthy \& Carter, 1994: 5). As such, I believe it is fair enough to focus our attention on language itself and investigate the Chilean official political rhetoric on education from the linguistic perspective, as at the end, "only in and through language can one issue commands, ask questions, make offers and promises. And only through language tied into social and political institutions can one declare war, declare guilty or not guilty, prorogue parliaments, or indeed raise or lower taxes ..." (Chilton \& Schäffner, 2002: 9).

To achieve this, I propose to look into the official political rhetoric in search for the linguistic choice around the term "education" in presidential speeches, or, to put it in other words, the entourage, or the predominant concepts and visions raised by the heads of the state on this topic from 2006 till 2013. This analysis will give us pure and undeniable empirical evidence on: 1) what education means for the government; 2) how it is seen by the first citizens of the country; and 3) what kind of values are introduced through it. This approach is claimed to be innovative as, to my knowledge the problem of education in Chile has been studied more from the socio-historical perspective (Schiefelbein, 2004; Cox, 2007; Bellei, Contreras \& Valenzuela, 2010) until now, and no attempts have been made to employ Linguistics to describe the concept of education in Chile during 20062013.

All things considered, the following section will give a detailed description of data and methods employed for the analysis. Furthermore, a profound discussion of the obtained results will be presented. 


\section{DATA AND METHODOLOGY}

On the 21st of May the President of Chile presents his / her annual discourse to the members of the Congress in order to account the country's administrative and political state of the nation. This tradition, also called the discourse of May, 21 st, is claimed to play an important role in Chile, since this presidential speech touches upon all main spheres of the country's affairs, including education. Providing that, and basing on the research interest of this paper, I collected a corpus of presidents' discourses pronounced in the country from 2006 to 2013. As put by Araya \& Farías (2014), in their monologue discourses, the presidents state what they consider adequate for certain context, pubic event or their ideological views. In doing so, it is quite challenging to look into presidential rhetoric in his / her annual address to the Congress in search for the concept of education and its representation by the first persons of the state. All these documents belong to public sources; thus, they can be freely consulted by anyone interested in them without previous request to the authorities.

Having this in mind, the next step of this research was to study the aforementioned corpus by drawing on a multi-layered interpretive framework (Maccarthy \& Carter, 1994: 5), involving corpus linguistics, political discourse analysis, and cognitive linguistics, so as to uncover ways in which the concept of education is covered in the official political discourse. In this respect, the crisscrossing of corpus-based approach with other linguistic domains (e.g., political discourse analysis) is based on the claim that "much research is now heavily departing from data encoded in computational resources" (Sousa \& Lourenço, 2012: 31). Moreover, the use of corpus tools for linguistic analysis allowed for "an objective and verifiable description of the relevant linguistic features of a text" (Macleod, 2005: 61) or larger corpora.

These tools can be used to electronically retrieve lexical units from the corpus laying out their corresponding frequencies ${ }^{1}$, and collocate them in concordance lines $^{2}$ to display their contexts of occurrence in order to proceed with a close analysis. As broadly put by Partington (1998: 66), concordance analysis can clear up both "the conceptual meaning of words and the connotational significance of lexis."

\footnotetext{
${ }^{1}$ We find it relevant for our analysis since "frequency is one of the most central concepts underpinning the analysis of corpora. It is important to understand that frequency lists are a good starting point and used sensitively they can illuminate a variety of interesting phenomena"(Baker, 2007: 47).

${ }^{2}$ As put in Baker (2007: 71), "a concordance is simply a list of all of the occurrences of a particular search term"; and "concordance analysis is one of the most effective techniques which allows researchers to carry out this sort of close examination."
} 
Thus, corpus linguistics will contribute to general corpus design (Sinclair, 1991; Meyer, 2002) as well as to its quantitative and qualitative analysis facilitated by the use of special software WordSmith@ (Scott, 2008). Providing that, the procedure employed manually-retrieval method of corpus collection to further put them all into one text format for their analysis with WordSmith@. Having done that, the final "tailor-made" corpus (Maunter, 2009) presented a collection of .txt documents (according to their authorship), which were fully ready for the analysis with the chosen software.

Furthermore, the study turned to the analysis of the concept of education per se through its thorough examination in the corpus. Mainly, it involved corpus-based approach to the analysis of the node "education" and its reference chains in the corpus. To achieve that, WordSmith(C) 6.0 was the main application used to investigate the chosen item. Further on, for a better analysis of target word and observed matching contexts, concordance lines were retrieved to demonstrate "a list of all the occurrences of a particular search term in a corpus, presented within the context that they occur in" (Baker, 2007: 71). For a concise illustration of the arguments in question, the speakers' messages in which the node occurs were also consulted. As put by Bolívar (2009: 30), "the analysis of concordance lines permits to explore the words with their immediate context to the left and to the right. More in particular, these collocations provide information on the words which tend to appear together with the keyword under the study". In addition, concordance lines and collocations of the word education were believed to give us semantic and pragmatic preferences around this word (Bolívar, 2009), or, in other words, a) lexicalsemantical fields of the term education; b) lexical choice around the term "education"; and c) the semantic prosody (Sinclair, 1991; Stubbs, 2001; Louw \& Chateau, 2010) of the lexicon used with the term "education", which "is not available to a priori intuition, but becomes visible "to the naked eye" only through corpus analysis" (Louw, 2010: 756). This semantic prosody, as claimed by Sinclair $(1990,2004)$ stands for the phenomenon in which a lexical unit acquires a "favourable or unfavourable connotation" (Partington, 1998: 66) according to its collocates.

Thus, a close reading of the corpus led to the search of a couple of instances (Biber, Conrad \& Repper, 1998) likely to uncover a more comprehensive display and analysis of their context of occurrence, and semantic prosody (Sinclair, 1991; Stubbs, 2001; Louw, 2010). The systematic analysis of the frequency of occurrence of the node "education", entailed the scrutiny of its context of occurrence, were it in the concordance lines (strings), at the sentence and textual levels. This further allowed for retrieving the context of occurrence of repeated patterns (for example, words, phrases or constructions), along with the search of co-occurring items "which have a high probability of being found together in a text or in a collection of texts of the same corpus" (Partington, 1998: 138).

Finally, the obtained results are discussed taking into account sociohistorical background of the selected discourses. 


\section{RESULTS AND DISCUSSION}

Based on the described techniques and procedures, our analysis has revealed that the quantitative variation of the topic of education in the presidents' discourses is embedded into the range [12-44]. Table 1 below demonstrates the raw and normalized ${ }^{3}$ frequency of use for the node education for each year. In this manner, we are able to observe the variation in raising the topic of education from the diachronic perspective. In particular, as can be seen in the table, education was mostly present in the presidential addresses in 2007 (2,6 times per 1000 words), 2013 (2,8 times per 1000 words) and 2014 (3,3 times per 1000 words); and least present in 2006 ( 1,1 times per 1000 words), 2008 ( 1,7 times per 1000 words) and 2009 (1,2 times per 1000 words). However, starting from 2010 we observe a steady growth of education topic in the discourses of May, 21st. In addition, this quantitative scale explicitly demonstrates that the topic of education was present rather in Piñera's than in Bachelet's discourses. Moreover, it became even more present during the last two years of his government.

In the case of President Bachelet, the frequency results show a variation range from 12 to 40, which demonstrates that the president paid more attention to the education topic in 2007 and 2008, leaving it aside in 2006 and 2009.

Table 1. Occurrence of the node "education" in Chilean presidential discourses of May, 21 st from 2006 to 2013

\begin{tabular}{|l|l|l|l|}
\hline & $\begin{array}{l}\text { Total words } \\
\text { N=number of words } \\
\text { in the corpus) }\end{array}$ & $\begin{array}{l}\text { Raw frequency of the } \\
\text { node "education" } \\
\text { (N=times in corpus) }\end{array}$ & $\begin{array}{l}\text { Normalized frequency of the } \\
\text { node "education" (N=times per } \\
\text { each 1000 words) }\end{array}$ \\
\hline 2006 & 11,270 & 12 & $\mathbf{1 , 1}$ \\
\hline 2007 & 15,365 & 40 & $\mathbf{2 , 6}$ \\
\hline 2008 & 20,703 & 35 & $\mathbf{1 , 7}$ \\
\hline 2009 & 15,479 & 18 & $\mathbf{1 , 2}$ \\
\hline 2010 & 17,047 & 33 & $\mathbf{2 , 0}$ \\
\hline 2011 & 14,302 & 32 & $\mathbf{2 , 2}$ \\
\hline 2012 & 18,014 & 41 & $\mathbf{2 , 3}$ \\
\hline 2013 & 15,902 & 41 & $\mathbf{2 , 8}$ \\
\hline
\end{tabular}

\footnotetext{
${ }^{3}$ As put in Biber et al. (1998, p. 263), "normalization is a way to adjust raw frequency counts from texts of different length so that they can be compared accurately."
} 
Having obtained these general quantitative results, the further analysis employed collocation function of WordSmith Tool to automatically generate concordance lines of the node education, as demonstrated in Figure 1 below.

Figure 1. An example of collocation lines automatically generated by WordSmith Tool for the node education in the dicourse of May, 21st in 2013

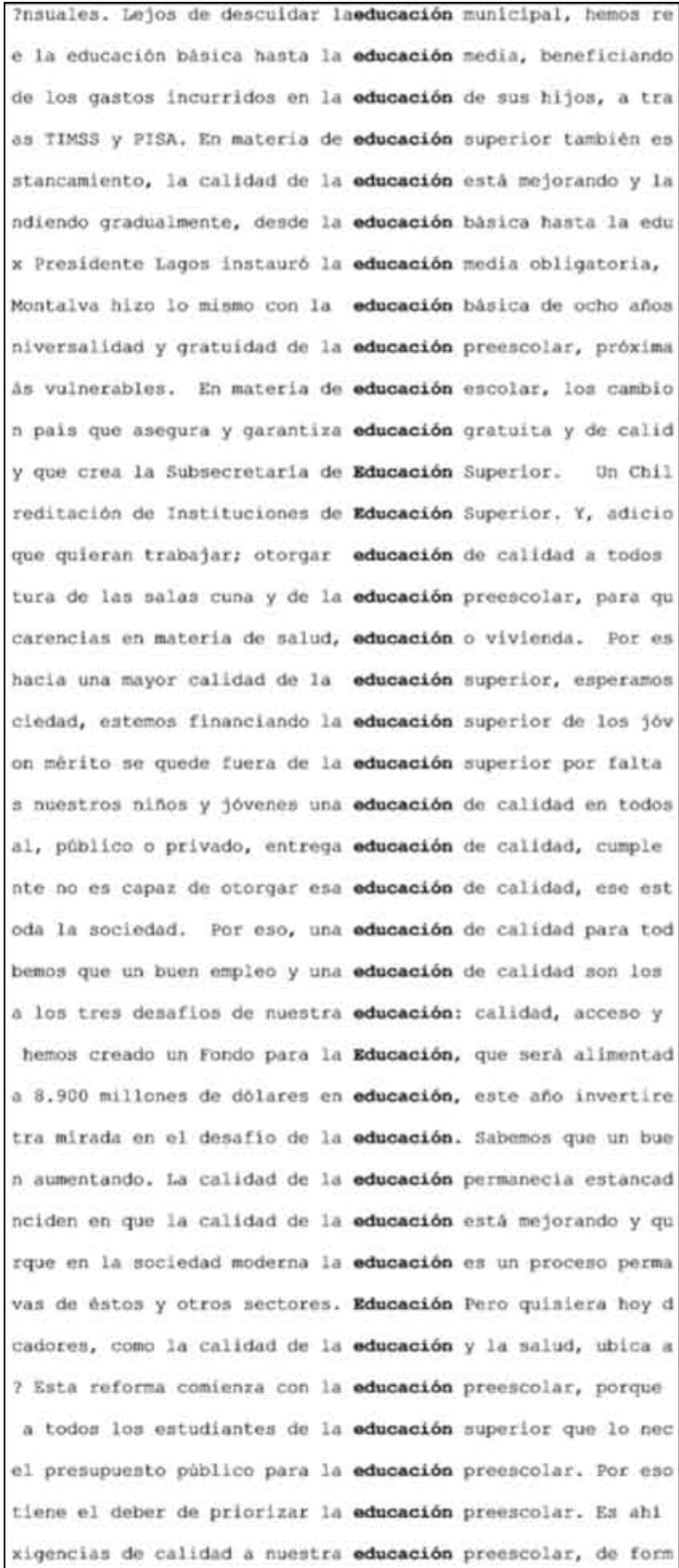


The close reading of the collocational lines and larger units (sentences) has been employed to determine the linguistic environment, or, to put in other words, semantic fields of the node under scrutiny. It consisted in tracking down the reference chains in search for the contexts of occurrences for the selected node. Thus, the analysis demonstrated that education was most frequently used with the words calidad (quality), superior (higher), pública (public) and para todos (for everybody). Therefore, these words are defined as four main semantic fields of the word education in the Chilean political discourse, 2006-2013. In its turn, these semantic fields represent a direct indication of the relationship between the state and education, more in particular, its role assigned by the government. In other words, the Chilean government sees and publicly presents education as closely connected to its quality, high level and open access (Diagram 1).

Diagram 1. Semantic fields of the node education $\left({ }^{*} \mathrm{~N}=\right.$ times per 1000 words)

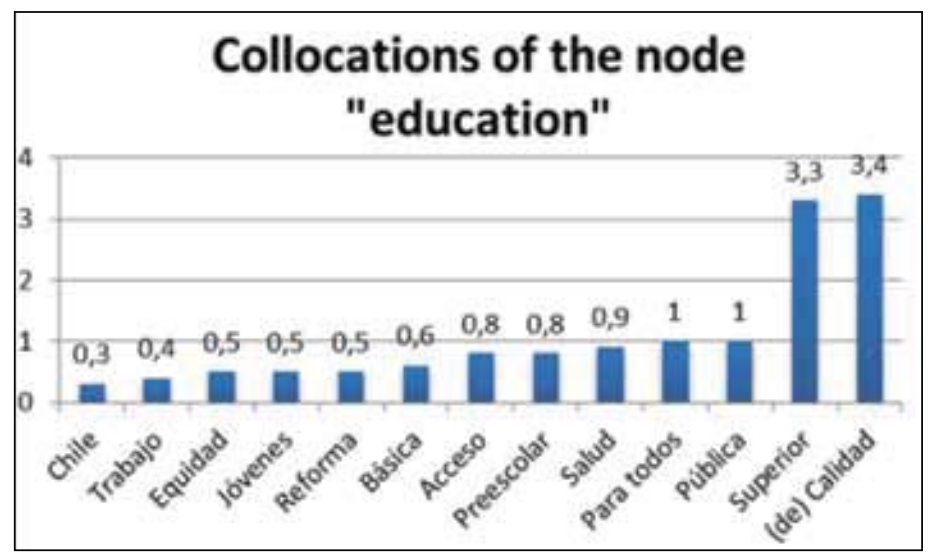

It should be stressed out at this point, that the first two collocations calidad (quality) and superior (higher) have a triple frequency prevalence $(\mathrm{N}=3,4$ and 3,3 times respectively) over the second two pública (public) and para todos (for everybody) ( $\mathrm{N}=1$ time). This result denotes that the presidents were promoting the concept of education by stressing out its connection first to quality and university level, and then to its public access. Further on, as can be seen in Diagram 1, other words used with education reveal a steady positive semantic prosody, which permits promoting education to the future public as an encouraging topic of appeal from the part of the government. Interestingly, according to the statistics of the National Council of Education, there was a double growth in the number of students enrolled in the universities since 2006 to 2013 all over the country.

Therefore, one might observe a direct correlation between first of all, the quantitative results of raising the topic of education during this period, and second of all, between the revealed semantic fields and semantic prosody chosen 
by the government to cover this issue. By stating this fact, I do not claim that the discourses of May, 21st and the representation of education in them have been the unique reasons of the increase in university enrollment in Chile. Rather, these results empirically demonstrate the (inter)connection between language, its use in particular settings, its adaptation to the social scenario in the country and its possible effect on the population.

However, taking into account different authorship and political views in the corpus, it was then divided into two different sections to see how the topic of education was represented by two different political wings in the country.

\section{"Education" and the central left wing government (M. Bachelet) in Chile, 2006-2013}

The above frequency results (cf. Table 1 ) demonstrate that the topic of education was raised 6,6 times per 1000 words in the whole corpus of the discourses pronounced by $\mathrm{M}$. Bachelet during her first government period. Furthermore, as stated above, the years 2006 and 2009 were when the topic of education was hardly mentioned by the president in her annual discourses. This fact becomes even more curious taking into account: 1) The beginning of massive student movements all over the country in 2006, and 2) Passing the Genereal Law of Education in 2009, which was negatively met by students as another facet of the old law (LOCE).

On the other hand, the presence of education issue became more prominent in 2007 and 2008, when the student movements were not that massive and the president seemed to acknowledge the public's demands by touching upon the main education concerns in her discourses of 2007 and 2008. Mainly, the reading of the concordance lines (and larger units) permits to evolve the following distribution of the semantic fields for the node education according to governing period.

Diagram 2. Semantic fields for the node education

in M. Bachelet's discourses 2006-2009

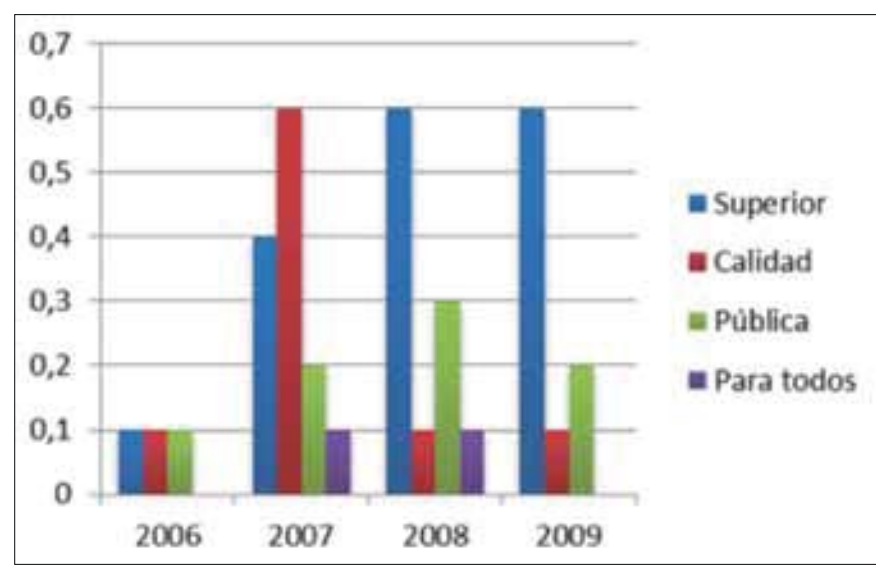


In terms of delivering the topic of education to the public, the president Bachelet is revealed to employ, as I defined it, mute and positive techniques. The mute technique happens when on the one hand, a certain topic is under a high public and / or country attention, but on the other - it is hardly touched by the head of the state in his / her public discourses. In our case, the example of this technique is the year 2006, which was marked by strong tensions between students and the government, including interventions from the part of the military forces. The main demand to the government was to introduce a new education policy with the main focus on the education of quality and equity. All these imply negative public attitude towards government education policy. Therefore, one of the logical scenarios would be the president's public reaction to the situation through the classic discourse of the 21st of May in Chile.

In this respect, the analysis has demonstrated that very year the "uncomfortable" topic of education was hardly mentioned by the president in her annual discourse. I believe that kind of technique was chosen to avoid possible negative reaction from the audience, which would probably lead to the deterioration of the situation in the country. However, this technique can be also seen as failing the public expectations, as most probably the public was waiting for the president's official explanations of the current situation in the country.

Further on, starting from 2007, the topic of education becomes a solid part in the president's discourses, which was defined as a positive technique to build a discourse on education. This positive technique implies the discourse construction based on linking the term education to the concepts with an explicit positive semantic prosody. However, apart from the quantitative raise, there was also a vivid change in the topic representation itself. In this respect, and as the government reaction to the last year developments in the country, the 2007 discourse was marked by connecting education mainly to the concepts of quality and superior studies. More in particular, the results demonstrate that in 2007 the topic of education was tightly linked to the concept of quality, while in 2008 and 2009, the situation significantly changed from "quality of education" towards "high education". Therefore, the results have directly reflected the political attitude towards education at that time. Mainly, the substitution of the old education law (LOCE) by a new General Law of Education in 2007, which was seen as a legal strength for the quality of education, the most associated term found with education in the present study for that year.

On the other hand, starting from 2008, the government decided to put more emphasis on the promotion of high education in the country, which was defined as an essential issue for the development of the country. However, as seen in the diagram 2 elsewhere, there is a considerable qualitative gap between "high education" and, for example, "quality of education" or "public education". 
This government pressure to introduce high education in the Chilean society is seen rather overwhelming, as if this political action could solve main education problems in the country.

\section{"Education" and the right wing (S. Piñera)}

As demonstrated by the quantitative analysis (cf. Table 1), the topic of education is presented in a continued growth in Piñera's discourses. Starting with its minimum use in $2010(\mathrm{~N}=33)$ and finishing with maximum in $2013(\mathrm{~N}=44)$. It is worth mentioning that this governing period was significantly marked by intense student movements and protests all over the country, expressing huge discontent of the society about education in the country. While in 2010 the topic of education was less covered by the president, most probably due to the severe problems caused by serious earthquake, in 2011 this topic came up to the scene again. What is more, this year was marked by new tense student movements (Seguel \& Farías, 2014), which ended up in tough strikes between students and the police. On top of that, the country experienced the change of three Ministers of Education during that year. All these events led to the fact that New York Times called that period Chilean winter: "If the Arab Spring has lost its bloom halfway across the world, people here are living what some have come to call a Chilean Winter" (Barrionuevo, 2011).

Further on, as demonstrated in Diagram 3, in 2011 the term education was mostly used with the collocates superior (high), leaving aside calidad (quality) and para todos (for everyone).

Diagram 3. Semantic fields for the node education in S. Piñera's discourses 2010-2013

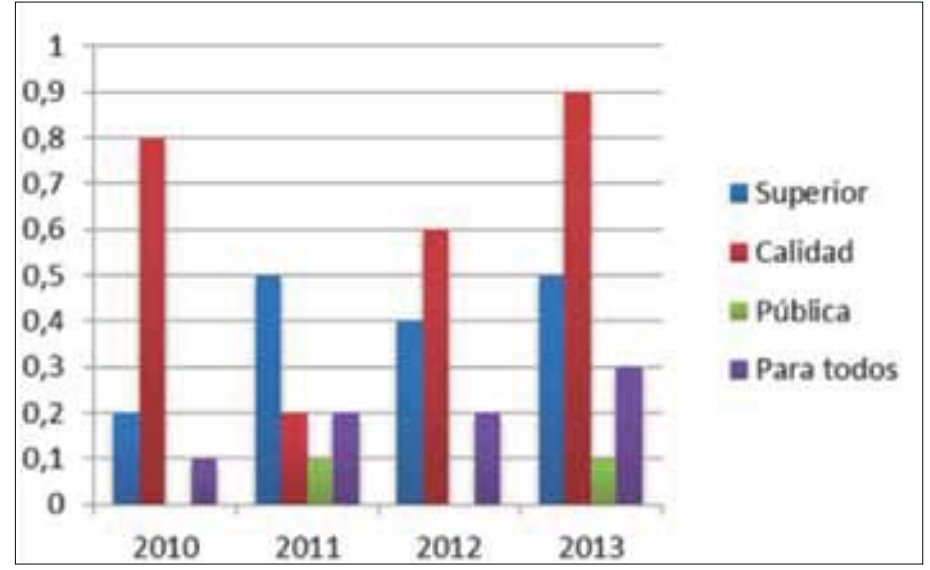


To support this result, Araya \& Farías (2014) in their study of Piñera's discourses on student movements in 2011, demonstrate that the president chose to delegitimize problems in education put forward by the students. At this point, the situation changed in the following 2012 and 2013, when the president started to associate education with quality again. As a result, the country experienced: 1 ) 12 billion dollars government investment into education system, and 2) Piñera's proposition of Law of Quality and Equity of Education in 2012 as a response to the continuous student movements and confrontations with the police.

Finally, in 2013 the topic of education got its highest rank since 2006 with the emphasis on quality of education and its university level as the main aim for country development. On top of that, in 2013 the president started the $3 \times 3$ program, designed to cover three levels of education - preschool, school and higher, basing on three main challenges - quality, access and funding, which clearly corresponds to the findings from his 2013 discourse.

\section{FINAL REMARKS}

The present study was aimed to investigate the topic of education in the official Chilean political discourse in order to determine the way it is viewed by the government. This objective was justified by the fact that education has been under a constant and broad public discussion all over the country, which at its extreme point provoked strikes between students and police. All this generated debates on the kind of education to be introduced in the country, what it should represent and how it should adapt to the public needs. In the light of these effects, I found it rather challenging to investigate this hot topic from linguistic perspective, taking into account the role of language in communicating political messages. More in particular, the study proposed to combine political discourse analysis and corpus linguistics as a method of analysis.

Thus, the obtained results have demonstrated a steady growth of the topic of education in presidents' discourses from 2006 till 2013. Moreover, the general tendency to collocate it with other terms demonstrate a close association of education with 1) the words calidad (quality) and superior (higher); and 2) the words with positive semantic prosody. As for the individual analysis for every government, the study reveals major stress on higher education from the part of M. Bachelet, and quality of education from S. Piñera's.

All in all, nowadays, the topic of education is still under broad discussion in Chile. In spite of the fact that the government introduces it through the terms of high value and positive semantic connotation, there is still a great part of citizens who are not fully satisfied with the educational policy in the country, and whose main concern still remains free education of high quality all over the country. 


\section{REFERENCES}

Araya, Claudio y Farías, Miguel. "El movimiento estudiantil del 2011 en intervenciones discursivas del Presidente Piñera”, Logos: Revista de Lingüistica, Filosofía y Literatura 24/1 (2014): 51-65.

Baker, Paul. Using Corpora in Discourse Analysis. London/New York: Continuum, 2007.

Barrionuevo, Alexei. With Kiss-Ins and Dances, Young Chileans Push for Reform. The New York Times. 2011. Viewed 25 November 2014: http://www.nytimes. com/2011/08/05/world/americas/05 chile.html?pagewanted=all \&_r=1\&

Bellei, Cristián, Contreras, Daniel y Valenzuela, Juan. "Viejos dilemas y nuevas propuestas en la política educacional chilena”. En Cristián Bellei, Daniel Contreras, and Juan P. Valenzuela (Eds.). Ecos de la revolución pingüina. Avances, debates y silencios en la reforma educacional. Santiago de Chile: Unicef, (2010): 11-27.

Biber, Douglas; Conrad, Susan \& Reppen, Randi. Corpus Linguistics: Investigating Language Structure and Use. Cambridge: Cambridge University Press, 1998.

Bolívar, Adriana. "Democracia" y "Revolución” en Venezuela: Un análisis crítico del discurso político desde la lingüística de corpus”, ORALIA 12 (2009): 27-54.

Chilton, Paul \& Schäffner, Christina. Politics as Text and Talk. Analytic Approaches to Political Discourse. Amsterdam and Philadelphia: John Benjamins, 2002.

Cox, Cristián. "Educación en el Bicentenario: dos agendas y calidad de la política", Pensamiento Educativo 40/1 (2007): 175-204.

Iaies, Gustavo y Delich, Andrés. "Sistemas educativos y cohesión social: La reconstrucción de "lo común" en los Estados Nacionales del siglo XXI". En Simon Schwartzman, and Cristián Cox (Eds.). Politicas Educativas y Cohesión Social en América Latina. Santiago de Chile: Uqbar editores y CIEPLAN, (2009): 175-230.

Louw, Bill \& Chateau, Carmela. "Semantic Prosody for the 21st Century: Are prosodies smoothed in academic contexts? A contextual prosodic theoretical perspective." Paper presented at the 10th International Conference on Statistical Analysis of Textual Data, Rome, Italy, (2010): 755-764. 
McCarthy, Michael \& Carter, Ronald. Language as Discourse: Perspectives for Language Teaching. London/New York: Longman, 1994.

Macleod, Norman. "Stylistics and Point of View in Fiction: A Credo and Some Examples", The European English Messenger ESSE 14/2 (2005): 61-73.

Mauntner, Gerlinde. "Corpora and Critical Discourse Analysis." In Paul Baker (Ed.). Contemporary Corpus Linguistics. New York: Continuum, (2009): 32- 46.

Meyer, Charles. English Corpus Linguistics: An Introduction. Cambridge: Cambridge University Press, 2002.

Morris, Paul \& Sweeting, Anthony. "Education and Politics: The Case of Hong Kong from an Historical Perspective", Oxford Review of Education 17/3 (1991): 249-267.

Partington, Alan. Patterns and Meanings: Using Corpora for English Language Research and Teaching. Philadelphia: John Benjamins, 1998.

Schiefelbein, Ernesto. "The politics of decentralisation in Latin America", International Review of Education 50 (2004): 359-378.

Scott, Mike. WordSmith Tools (Version 5.0). Liverpool: Lexical Analysis Software, 2008.

Sinclair, John. Collins Cobuild English grammar. London/Glasgow: Collins, 1990.

Sinclair, John. Corpus, concordance, collocation. Oxford: Oxford University Press, 1991.

Sinclair, John. Developing Linguistic Corpora: A Guide to Good Practice. Ahds literature, languages and linguistics. 2004. Viewed 24 November 2014: www. ahds.ac.uk/creating/guides/linguistic-corpora/chapter1.htm\#section1 1

Sousa, Alcina \& Lourenço, Julia. "The Rhetoric of Regional Planning: A Crossdisciplinary approach”, Topics in Linguistics 9 (2012): 28-41.

Stubbs, Michael. Words and Phrases. Oxford: Blackwell, 2001. 